Список використаних джерел.

[1] Hollifield B., Alarm management handbook, 2nd ed., Pas, 2010.

[2] Mission. [Електронний pecypc] // Asmconsortium.net. - 2021. - Режим доступу до ресурсу: https://www.asmconsortium.net/defined/mission/Pages/default.aspx.

[3] EEMUA Publication 191 Digital. [Електронний pecypc] // Eemua.org. - 2021. - Режим доступу до ресурсу: https://www.eemua.org/Products/Publications/Digital/EEMUA-Publication-191.aspx.

[4] ANSI/ISA-18.2-2016. Management of Alarm Systems for the Process Industries. USA: ISA standards and Practices board, 2016.

[5] Пупена О. М., Шишак А. В. Сучасні стандарти з розроблення тривожної сигналізації в автоматизованих системах керування технологічними процесами. Автоматизація технологічних і бізнес-процесів, 2019. 11(3). c. 46-58.

[6] Пупена О.М. Розроблення людино-машинних інтерфейсів та систем збирання даних 3 використанням програмних засобів SCADA/НMI.: Навч. посіб. Київ : Видавництво Ліра-К, 2020. - 594 с.

[7] ISA-TR18.2.2-2016. Alarm Identification and Rationalization. USA: ISA standards and Practices board, 2016. c.42.

[8] ISA-TR18.2.3-2015. Basic Alarm Design. USA: ISA standards and Practices board, 2015. c.52.

[9] ISA-TR18.2.5-2012. Alarm System Monitoring, Assessment, and Auditing. USA: ISA standards and Practices board, 2012. c.68.

References.

[1] B. Hollifield, Alarm management handbook, 2nd ed., Pas, 2010.

[2] "Mission", $\quad 2021$. https://www.asmconsortium.net/defined/mission/Pages/default.aspx. [Accessed: 04- Jan- 2021]

[3] "EEMUA $\quad$ Publication $191 \quad$ Digital", $\quad$ Eemua.org, $2021 . \quad$ [Online]. Available: https://www.eemua.org/Products/Publications/Digital/EEMUA-Publication-191.aspx. [Accessed: 04- Jan- 2021].

[4] ANSI/ISA-18.2-2016, Management of Alarm Systems for the Process Industries, ISA standards and Practices board, 2016.

[5] O. Pupena and A. Shyshak, Modern standards of alarm management in process control systems, ATBP, vol 11, no 3, pp 46-58, Nov 2019.

[6] O. Pupena, Development of human-machine interfaces and data collection systems using SCADA/HMI software. Kyiv: Lira-K, 2020.

[7] ISA-TR18.2.2-2016, Alarm Identification and Rationalization, ISA standards and Practices board, 2016.

[8] ISA-TR18.2.3-2015, Basic Alarm Design, ISA standards and Practices board, 2015.

[9] ISA-TR18.2.5-2012, Alarm System Monitoring, Assessment, and Auditing, ISA standards and Practices board, 2012.

Отримана в редакції 05.01.2021. Прийнята до друку 22.02.2021. Received 05 January 2021. Approved 22 February

2021. Available in Internet 31 March 2021.

УДК 004.896:664.844.02

\title{
АВТОМАТИЧНЕ КЕРУВАННЯ ПРОЦЕСОМ СУШНННЯ ПЛОДООВОЧЕВОЇ СИРОВИНИ В КОНДЕНСАЦІЙНІЙ ТЕРМОЕЛЕКТРИЧНІЙ СУШАРЦІ
}

Якубаш I. В.

Одеська національна академія харчових технологій, м. Одеса, Україна

ORCID: 0000-0002-2260-410X

E-mail: jakubash@ukr.net

Copyright (C) 2021 by author and the journal “Automation of technological and business - processes”.

This work is licensed under the Creative Commons Attribution International License (CC BY).

http://creativecommons.org/licanses/by/4.0

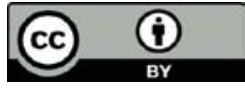

ONAFT

Open Access

DOI:

Анотація. Сушіння є одним з найбільи ефективних методів збереження сільськогосподарських $i$ харчових продуктів. Якість висушеного продукту залежить від дотримання регламенту технологічного процесу сушіння. 
Підвищення якості ведення технологічного процесу (ТП) сушіння плодоовочевої сировини впливає на якість виготовленої продукції, що, в свою чергу, призводить до підвищення конкурентоспроможності підприємства. Дотримання регламенту ТП можливе лише за його автоматизації. Тому завдання автоматизаиії ТП дедалі більше постає перед сучасними підприємствами. Огляд існуючих вітчизняних розробок в сфері автоматизації сушіння, зокрема сушіння плодоовочевої сировини, показує наявність суттєвих недоліків. В ОНАХТ, на кафедрі АТП $і$ РС у рамках випускної роботи бакалавра розроблено новий підхід до автоматизації керування конденсаційною сушаркою, задля забезпечення високоефективного сушіння плодоовочевої сировини. Метою роботи є розробка найдосконалішої математичної моделі, функиія якої б полягала в відтворенні основних властивостей середовища сушіння сільськогосподарських та харчових продуктів, з можливістю їхнього відображення та дослідження. В роботі розкрито мету ТП сушіння та виділено основні технологічні параметри, для яких необхідно скласти регламент, для забезпечення високої якості готової продукиії. Складено структурну схему моделі об'єкта керування. Проведено аналіз його каналів зв'язку та їх ідентифікацію. Канали математично описано статичними аперіодичними ланками другого порядку. Розроблено модель id-діаграми вологого повітря, яка є достовірною. Також розроблено повну математичну модель об'єкту керування і зроблено висновки про можливість ї̈ використання у подальших розробках як основу при синтезі моделі системи автоматичного регулювання. На кафедрі АТП і РС було реалізовано фізичну модель, яка працює з відповідними встановленими параметрами та відповідає всім перехідним процесам.

Abstract. Drying is one of the most effective methods of preserving agricultural and food products. The quality of the dried product depends on compliance with the regulations of the drying process. Improving the quality of the technological process (TP) of drying fruit and vegetable raw materials affects the quality of manufactured products, which in turn affects the competitiveness of the future enterprise. Compliance with TP regulations is possible only with its automation. The issue of automation of technological processes is increasingly facing modern enterprises. An overview of existing developments in particular drying of fruit and vegetable raw materials shows the presence of significant shortcomings. In ONAFT at the department of ATP and RS as part of the bachelor's thesis it's developed a new approach to automation of condensation dryer control for efficient drying of fruit and vegetable raw materials. The aim of the work is to develop the most advanced mathematical model, the function of which would be to reproduce the basic properties of the drying environment of agricultural and food products, with the possibility of their reflection and study. The purpose of TP drying was revealed and the main technological parameters on which it is necessary to impose regulations in order that quality of initial production was corresponding were allocated. The block diagram of the model of the control object is made. It's analyzed its communication channels and their identification. These channels were mathematically described by static aperiodic links of the second order. The developed model of the id-diagram of humid air is reliable. A complete mathematical model of the control object is presented and a conclusion is made about the possibility of its use in further developments. The model is designed so that in the future it could be used as a basis for the synthesis of the model of the automatic control system. At the Department of ATP and RS was implemented a physical model that works with the appropriate set parameters and meets all the transients.

Ключові слова: автоматизація, керування, сушіння, плодоовочева сировина, сушарна камера, id-діаграми, конденсаційна термоелектрична сушарка.

Key words: automation, control, drying, fruit and vegetable raw materials, drying chamber, id-diagrams, condensing thermoelectric dryer.

Вступ. Сушіння - це процес видалення вологи, що забезпечується іï випаровуванням і відведенням пари. Під сушінням розуміють сукупність термічних і масообмінних процесів у поверхні (зовнішнє завдання) i всередині (внутрішнє завдання) вологого матеріалу, що сприяють його зневодненню. Зневоднення харчових продуктів, у тому числі і сушіння, призначено для покращення їхньої якості при довготривалому зберіганні. Швидкість протікання цих процесів та ступінь їхньої завершеності залежить не тільки від способу підведення теплоти до матеріалу, а й від режиму сушіння. При тепловому сушінні видалення вологи 3 матеріалу відбувається в основному шляхом випаровування.

Найпоширеніший спосіб теплового сушіння - конвективний. У конвективних сушарках теплоту процесу несе газоподібний сушильний агент (нагріте повітря), який є безпосередньо дотичним з поверхнею матеріалу. Пари вологи несуться тим самим сушильним агентом. У сушарках багатьох типів зі зваженим шаром сушильний агент служить не тільки тепло- і вологоносієм, але і транспортним середовищем для дисперсного матеріалу.

Швидкість процесу сушіння вологого матеріалу нагрітим повітрям залежить від інтенсивності зовнішнього, внутрішнього теплообміну і масообміну, оскільки від цих процесів залежить кількість вологи, підведеної до поверхні випаровування.

Сушильний агент виконує і друге, не менш важливе завдання - поглинає утворений водяний пар і виводить його 3 сушарки. Таким чином, при нагріванні матеріалу, інтенсивність даного процесу залежить від швидкості перенесення теплоти, випаровування вологи, а також від швидкості перенесення маси цієї вологи в сушильний агент. Оскільки топкові гази містять в своєму складі тверді продукти згоряння, що призводять до забруднення висушених матеріалів, в харчовій промисловості вони практично не застосовуються. Тут найпоширенішим сушильним агентом $\epsilon$ попередньо підігріте повітря.

Для сушіння матеріалів, що вимагають підвищеної вологості сушильного агента і невисоких температур, застосовують пристрої, що забезпечують рециркуляцію (повернення) частини відпрацьованого повітря в сушарку, а 
також сушарки 3 проміжним підігрівом повітря між окремими ступенями (або зонами) і його одночасною рециркуляцією. При сушінні матеріалів, які важко сохнуть та для поліпшення їхньої сипучості, застосовують рециркуляцію частини висушеного продукту, тобто повернення його на вхід сушарки та змішування 3 вихідним матеріалом.

Під час сушіння (при видаленні вологи разом з паром) з продукту видаляються цінні ароматичні сполуки (спирти, ефіри, альдегіди та ін.). Для збору ароматичних сполук застосовують схеми сушіння з замкнутим циклом, що включає в себе пристрій для конденсації парів ароматичних речовин.

Якість висушеного продукту залежить від дотримання регламенту технологічного процесу (ТП) сушіння. Дотримання регламенту ТП можливе лише за його автоматизації. Тому завдання автоматизації ТП процесу сушіння $є$ вельми актуальним і дедалі більше постає перед сучасними підприємствами. Багато авторів займались питанням автоматичного управління процесом сушіння плодоовочевої сировини, де було розглянуто цей процес як ОК. В.А. Соколов запропонував спосіб автоматичного управління, де розглянуто ОК з наступними регламентованими параметрами: температура вхідного повітря в камеру сушарки та відносна вологість на вході в камеру сушарки під час сушіння плодоовочевої сировини [1]. Н.О. Вороніна та А.В. Казаков в спільно розробленій системі автоматичного управління розглянули ОК як процес, в ході якого необхідно накладати регламент на температуру холодної води, температуру холодного повітря та вологість холодного повітря в сушарці під час сушіння сировини [2]. ОК як процес, в ході якого регламентують температуру, відносну вологість в повітрі, яке надходить до сушарної камери, розглянули А.А. Корольов та В.Б. Пенто [3 - 5].

Всі згадані вище дослідники при побудові системи автоматичного керування, визначаючі параметри процесу сушіння плодоовочевої сировини та способи управління, домагалися досягнення готовності продукту за занадто великий час. Також не проводився синтез та аналіз САР процесу сушіння, аналіз показників якості розроблених САР, не обгрунтовано доцільність використання обраних принципів автоматичного регулювання для сукупності всіх необхідних регламентних параметрів процесу сушіння, відтворення основних властивостей середовища сушіння. У жодному з розглянутих досліджень процесу сушіння не розглянуто можливість відбирання побічного продукту «конденсату» за допомогою, наприклад, термоелектричного насоса, який є високоенергоефективним. Не розглянуто питання економії енергоресурсів та охорони навколишнього середовища.

В Одеській національній академії харчових технологій, на кафедрі автоматизації технологічних процесів та робототехнічних систем, у рамках випускної роботи бакалавра запропоновано новий підхід до автоматизації керування конденсаційною сушаркою, задля забезпечення високоефективного сушіння плодоовочевої сировини. Метою роботи була розробка найдосконалішої математичної моделі, функція якої б полягала в відтворенні основних властивостей середовища сушіння сільськогосподарських та харчових продуктів, 3 можливістю їхнього відображення та дослідження [6].

В дослідженні, на основі технічного аналізу процесу сушіння, з позиції його автоматизації визначено параметри, які мають найбільший вплив на процес, обгрунтовано вимоги до системи автоматизації та обрано технічні засоби для iii реалізації. Розроблено математичну модель середовища сушіння продукту в сушарці, в якій враховано залежність відносної вологості та температури від вологовмісту та температури і вологовмісту від відносної вологості. Проведено синтез та аналіз САР процесу сушіння, в якому враховують температуру та вологість вхідного повітря. Обгрунтовано використання доцільних принципів автоматичного регулювання та проведено аналіз показників якості розробленої САР різних варіантів.

\section{Основна частина}

Суть ТП - цілеспрямоване перетворення матеріальних та енергетичних потоків у спеціальному технологічному устаткуванні (машинах, апаратах, агрегатах) з видалення зі складу продукту вологи до заданого рівня вологовмісту при дотриманні регламентованих температурних режимів. Підтримання необхідної температури і вологості в камері сушіння дає можливість отримати 3 мінімальними витратами енергії високоякісний готовий продукт. Використання у складі сушарки конденсаційного утилізатора тепла дає можливість отримати побічний продукт - конденсат 3 розчиненими в ньому натуральними ароматичними речовинами, а також зменшити питомі енергетичні витрати та кількість викидів у навколишнє середовище.

Процес сушіння здійснюється методом конвективного видалення вологи з продукту. Завантажуючи початковий продукт в камеру, його розміщують на лотки, що мають сітчасту поверхню. Камера має 7 лотків місткістю 50 кг продукту на 1лоток. Робочий об'єм сушарної камери з решетами - 3000 л. Знизу, під лотками, розміщений вентилятор, який подає нагрітий сухий сушильний агент в кільцевий перфорований повітряний канал, що розташований по периферії камери сушіння, а з нього - в проміжки, що розташовані між лотками з продуктом. У центрі сушарки крізь лотки проходить перфорована труба, завдяки якій насичений вологою сушарний агент виходить 3 камери, і потрапляє на охолодження термоелектричного теплового насосу «повітря - повітря». Там він охолоджується майже до температури точки роси, при якій його відносна вологість становить 95-98 \%. Охолоджений сушарний агент далі потрапляє до конденсатора, де він переохолоджується нижче від точки роси з утворенням конденсату, який стікає до збірника. При цьому його абсолютна вологість зменшується. 3 виходу конденсатора переохолоджений сушильний агент, з відносною вологістю 100\%, потрапляє на вхід теплового насосу «вода-повітря», де він підігрівається на 10$20^{\circ} \mathrm{C}$, а його відносна вологість знижується до 50-70\%. 3 виходу теплового насосу «вода-повітря» підігрітий сушарний агент потрапляє на вхід теплового насосу «повітря-повітря», де він підігрівається ще на $10-20^{\circ} \mathrm{C}$, а його відносна 
вологість знижується до 15-30\%, що відповідає заданим параметрам на вході в камеру сушіння. Змінюючи температуру сушарного агенту на виході з конденсатора (Тх.воз.) можливо змінювати відносну вологість повітря на вході в сушарну камеру, або витрати конденсату. Безперервно регульованими параметрами в процесі сушіння $є$ Т температура і М - вологість. Для нагріву повітря використовується ТНПП (термоелектричний перетворювач) №2 ТНПВ №1 - використовуємо для охолодження води, яка, в свою чергу, охолоджує повітря на виході 3 конденсатора до необхідної температури, та насичує його вологістю до 100\%. На вологість повітря, яке нагнітається в сушарну камеру, саме і впливає ця температура (холодного повітря на виході з конденсатора) (рис. 1).

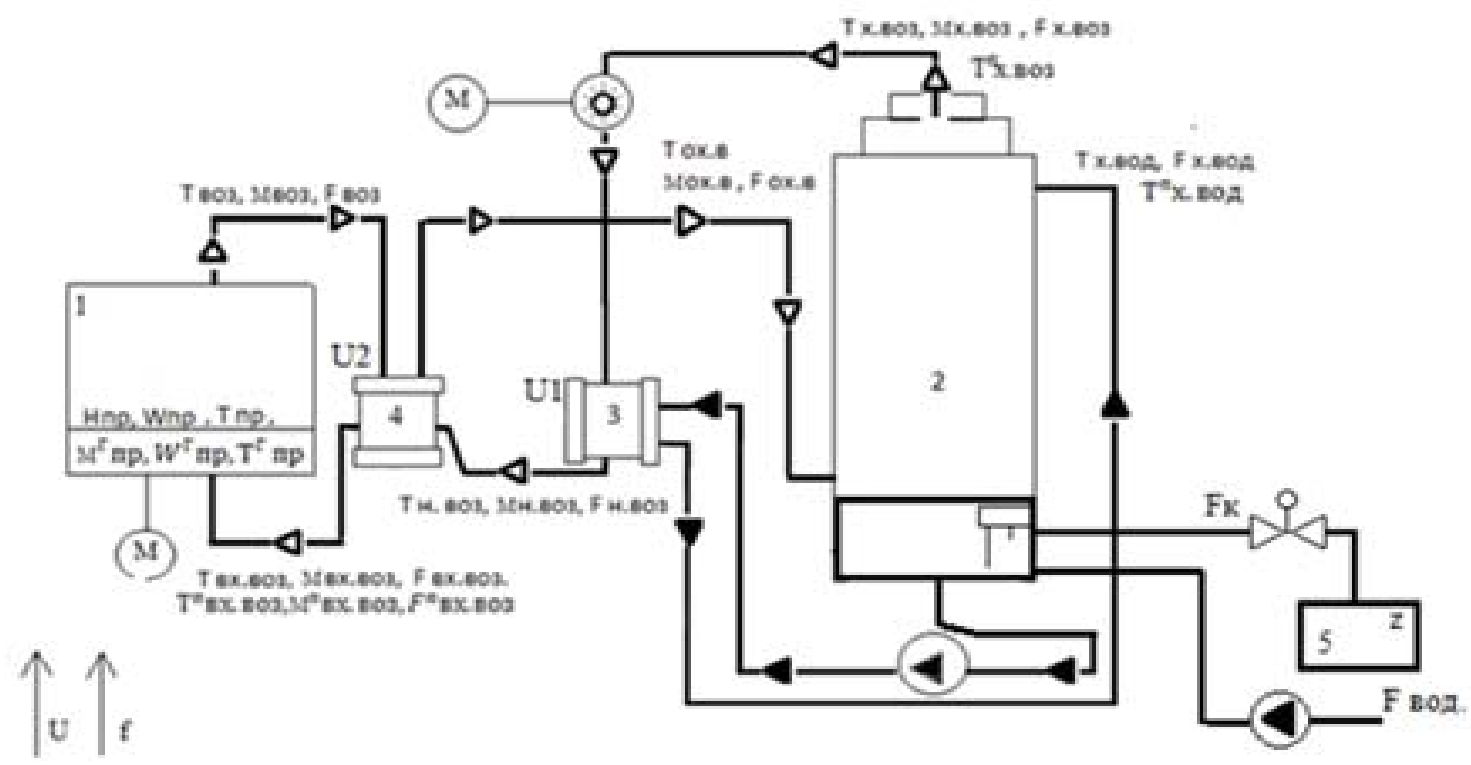

Рис. 1 - Параметризована технологічна схема процесу сушіння як об'єкту керування

1-Сушарна камера. 2-Конденсаџійний теплообмінник (далі "конденсатор"). 3-Термоелектричний тепловий насос «повітря-вода» (ТНПВ). 4-Термоелектричний тепловий насос «повітря - повітря» (ТНПП).

\section{5 - Резервуар для збору конденсату.}

Позначення на параметризованій технологічній схемі на рис.1:

$M^{\Gamma}$ пр - вологість готового продукту

$W^{\Gamma}$ пр - маса готового продукту в камері

$\mathrm{T}^{\Gamma}$ пр - температура готового продукту

F к. - витрати конденсата

Т воз. - температура повітря на виході з камери

М воз. - вологість повітря на виході з камери

F воз. - витрати повітря на виході з камери

Т ох.в - температура охоложенного повітря на виході з ТНПП

М ох.в - вологість охоложенного повітря на виході $з$ ТНПП

F ох.в - витрати охоложенного повітря на віході 3 ТНПП

Т х.воз. - температура охоложенного (насиченого вологою) повітря на виході з конденсатора. М х.воз. - вологість охоложенного (насиченого вологою) повітря на виході 3 конденсатора

F х.воз. - витрати охолодженного (насиченого вологою) повітря на виході з конденсатора Т х.вод. - температура подачі холодної води в конденсаторі
М н.во3. - вологість нагрітого повітря на виході з ТНПВ

F н.воз. - витрати нагретого повітря на виході з ТНПВ.

T вх.воз. - температура вхідного нагрітого повітря в сушарку

М вх.воз. - вологість вхідного нагрітого повітря в сушарку

F вх.воз. - витрати вхідного нагрітого повітря в сушарку

М пр -вологість продукту завантаженого в камеру сушіння

T пр - температура продукту U- напруга мережі

Т н.воз. - температура нагрітого повітря на виході 3 ТНПВ

u1 - положення регулюючого органу, що регулює струм ТЕП1 теплового насосу ТНПВ

u2 - положення регулюючого органу, що регулює струм ТЕП2 теплового насосу ТНПП

W пр - маса продукту в камері

f - частота змінної напруги в електромережі

F х.вод. - витрати холодної води в конденсаторі

(M- електродвигун, -

Наступним та логічно завершеним етапом побудови математичної моделі ОК була розробка ії структурної схеми (рис. 2). Поняття «параметр» було замінено поняттями «вплив» та «змінна». 


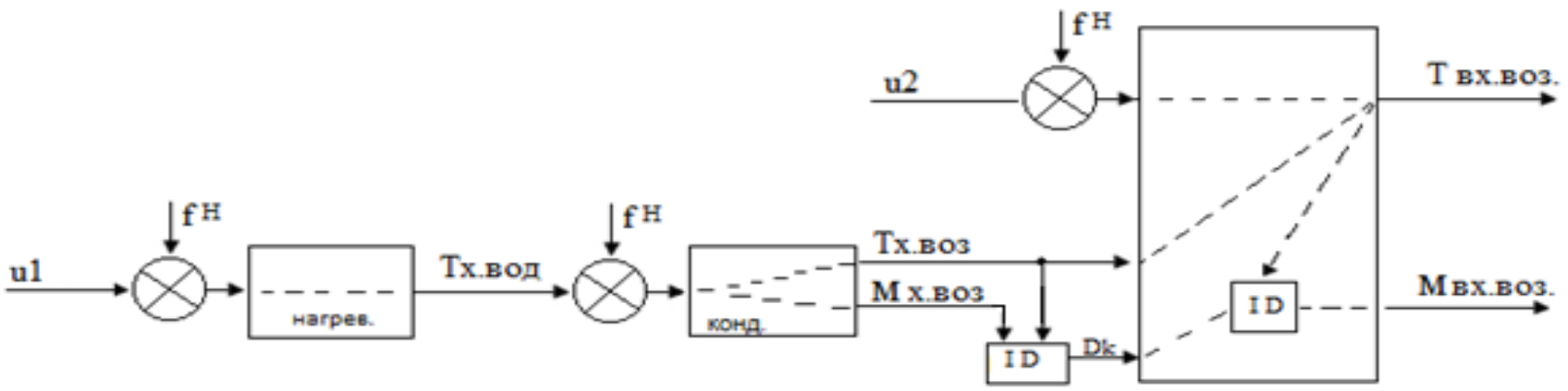

Рис. 2 - Структурна схема моделі ОК

ul i и2 - положення регулюючого органу; ID - Id діаграма; Dk-вологовміст; $f_{H}$ - вектор неконтрольованих збурень;

Зв'язки між змінними на структурній схемі моделі ОК (рис. 2), що відображені пунктирними лініями (канали ОК), $\epsilon$ причино-наслідковими та можуть бути описані як математичні моделі диференційними рівняннями другого і більших порядків. В нашому випадку, враховуючи властивість каналів ОК, до самовирівнювання використано статичні аперіодичні ланки другого порядку.

Було проведено серію активних експериментів, суть яких полягала в подачі ступінчатого сигналу керуючої дії на окремі (по черзі) входи ОК (U1, U2), з реєстрацією значень всіх вихідних змінних (T, M) та отримання експериментальних перехідних характеристик (ЕПХ). Для того, щоб отримати необхідні коефіцієнти рівнянь (параметри моделей каналів ОК), проведено параметричну ідентифікацію за ЕПХ. Як результат, одержано доступні для подальших експериментів математичні моделі каналів ОК (таблиця 1).

Таблиця 1 - Результати параметричної ідентифікації

\begin{tabular}{|c|c|c|}
\hline \multirow{2}{*}{ Канал ОУ } & \multicolumn{2}{|c|}{ Модель динаміки } \\
\hline & 1-го порядку & 2-го порядку \\
\hline$\underline{\mathrm{u} 1 \text { - Т х.во3. }}$ & $\mathrm{W}_{\mathrm{u} 1 \mathrm{~T}_{\mathrm{x} . \mathrm{sos}}}(\mathrm{p})=-\frac{0.25 * \mathrm{e}^{-345 \mathrm{p}}}{182.5 p+1}$ & 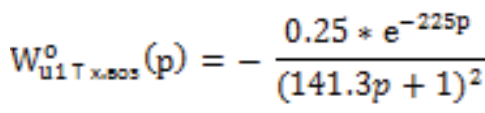 \\
\hline u1- Т х.вод & $\mathrm{W}_{\mathrm{u} 1 \mathrm{~T} \times \mathrm{BOA}}^{\circ}(\mathrm{p})=-\frac{0.2 * \mathrm{e}^{-64.5 \mathrm{p}}}{173.8 p+1}$ & $\mathrm{~W}_{\mathrm{u} 1 \mathrm{~T}_{\mathrm{x} B \mathrm{BA}}}^{\circ}(\mathrm{p})=-\frac{0.2 * \mathrm{e}^{-37,5 \mathrm{p}}}{(98.1 p+1)^{2}}$ \\
\hline$\underline{\mathrm{u} 1-\mathrm{T} \text { вХ.во3 }}$ & $\mathrm{W}_{\mathrm{u} 1 \mathrm{~T} \operatorname{sc.sos}}^{\circ}(\mathrm{p})=\frac{0.15 * \mathrm{e}^{-110 \mathrm{p}}}{240 p+1}$ & $W_{\mathrm{u} 1 \mathrm{~T} \operatorname{sx} . \mathrm{sos}}^{\circ}(\mathrm{p})=\frac{0.15 * \mathrm{e}^{-27,5 \mathrm{p}}}{(154 p+1)^{2}}$ \\
\hline$\underline{\mathrm{u} 2-\mathrm{T} \text { вх.во3 }}$ & $W_{\mathrm{u} 2 \mathrm{~T} \operatorname{sx.50}}^{\circ}(\mathrm{p})=\frac{0.2 * \mathrm{e}^{-102 \mathrm{p}}}{87.5 p+1}$ & $W_{\mathrm{u} 2 \mathrm{Tsx} \cdot \mathrm{sos}}^{\circ}(\mathrm{p})=\frac{0.2 * \mathrm{e}^{-33 \mathrm{p}}}{(72.5 p+1)^{2}}$ \\
\hline
\end{tabular}

Як видно з рис. 2, в структурній схемі фігурує два таких елемента, як id-діаграми вологовмісту та вологого повітря. Відомо, що id-діаграма вологого повітря графічно пов'язує всі параметри, що визначають тепловологісний стан повітря: ентальпію, вологовміст, температуру, відносну вологість, парціальний тиск водяної пари. Якщо не врахувати при моделюванні фізичний закон, який вона описує, то розроблена модель не буде достовірною.

Для моделювання середовища сушіння продукту (моделювання ОК) впевнено скористались пакетом прикладних програм «Matlab», а саме графічним середовищем імітаційного моделювання «Simulink». Прийнято рішення змоделювати динаміку ОК (табл. 1) за допомогою блоку «Transfer Fcn» з стандартної бібліотеки «Simulink».

Для імітації фізичного закону, суть якого відображена на id-діаграмі (рис. 3), було використано блок з стандартної бібліотеки Simulink «Look - Up Table 2D». Дані у блоках id-діаграми (Тх.воз+Mx.воз=Dk) та id-діаграми (Dk+Твх.воз=Мвх.воз) зберігаються у вигляді таблиці (рис. 4) та були введені після графічного визначення вологовмісту, в залежності від відносної вологи та температури, та проведено визначення відносної вологості, в залежності від вологовмісту та температури по id-діаграмах. 


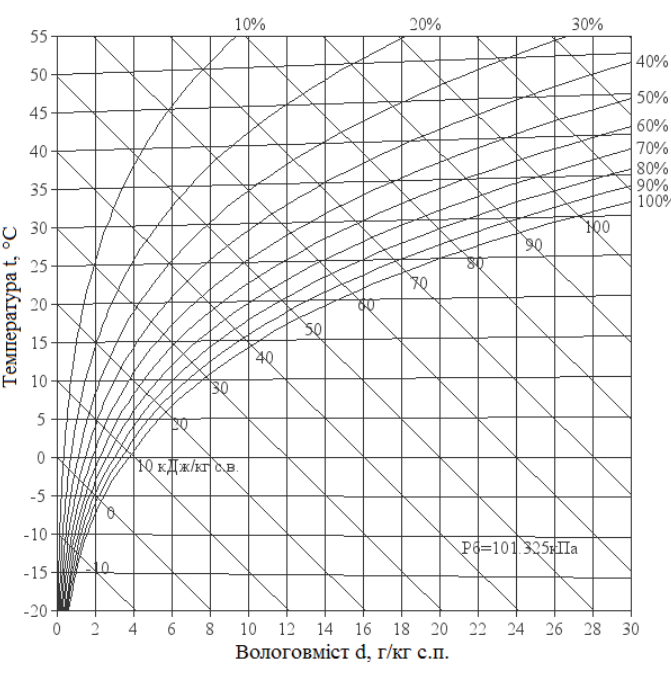

Рис. 3 - id-діаграма вологого повітря

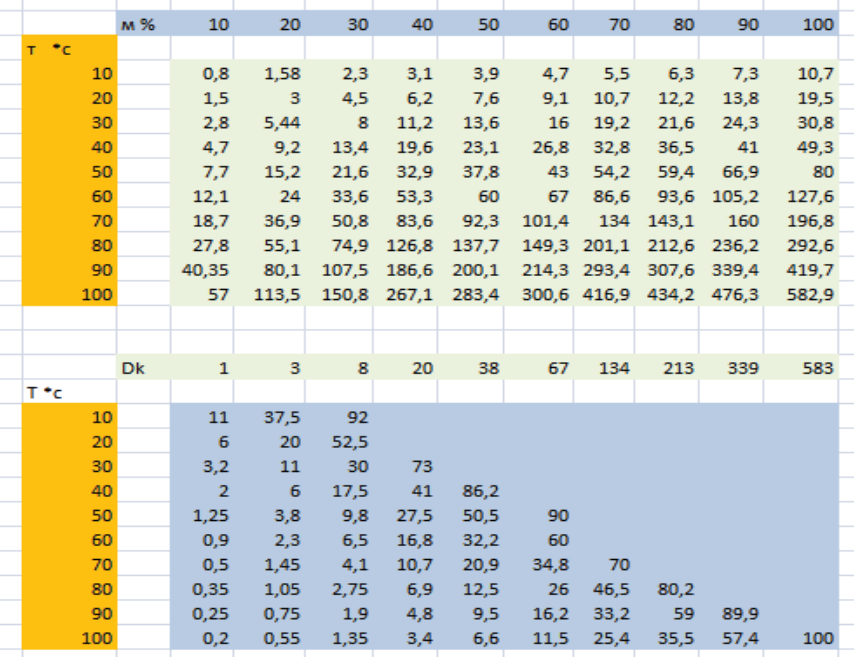

Рис. 4 - Вміст блоку «Look - Up Table 2D»

3 рис. 3, 4 видно, що для кожного значення температури (в межах $0-100^{\circ} \mathrm{C}$ ) та вологовмісту (в межах $1-583$ г/кг) існує відповідне значення відносної вологості $(0-100 \%)$. Так само й навпаки, для кожного значення температури та вологості існує відповідне значення вологовмісту. Важливо відмітити, що блок «Look - Up Table 2D» може інтерполювати та екстраполювати значення. В даному випадку функція інтерполювання відіграє дуже важливу роль, адже в процесі моделювання до блоку можуть записуватись значення температури та вологовмісту, що не записувались до таблиці (наприклад, значення температури $30 \ldots 40^{\circ} \mathrm{C}$ ). Функцію екстраполювання необхідно обмежити бо зрозуміло, що відносна волога не може бути більша, ніж 100 \%. Враховуючи цю особливість, в модель діаграми на вході встановимо обмеження $0-100$.

Відносно іншого блоку, - в ньому встановлено обмеження стосовно вологовмісту, оскільки при максимальній відносній вологості в $100 \%$ та температурі в $100^{\circ} \mathrm{C}$ вологовміст досягає максимального показника в 583 г/кг. Враховуючи цю особливість, в модель діаграми на вході встановлено обмеження 0 - 583.

Моделі діаграм зображено на рис. 5.

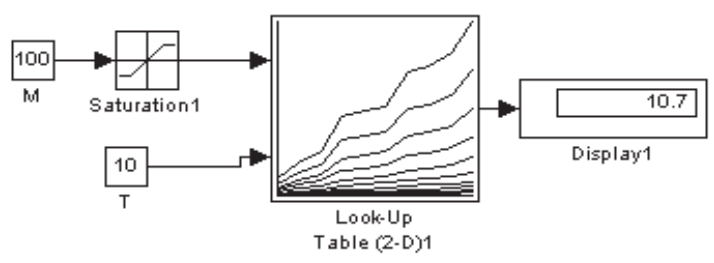

ІД - діаграма $(T x . в о з+M x . в о з=D k)$

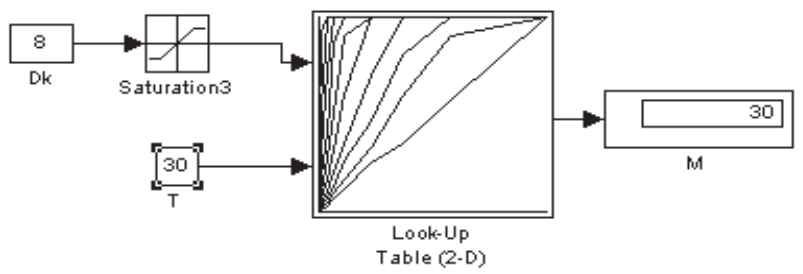

ІД - діаграма $(D k+$ Твх.воз $=$ Мвх.воз $)$

Рис. 5 - Моделі id-діаграм

На основі моделей динаміки та моделі статики (моделі id-діаграм) розроблено повну модель ОК (рис. 6). В повній моделі ОК також присутні моделі неконтрольованих збурень.
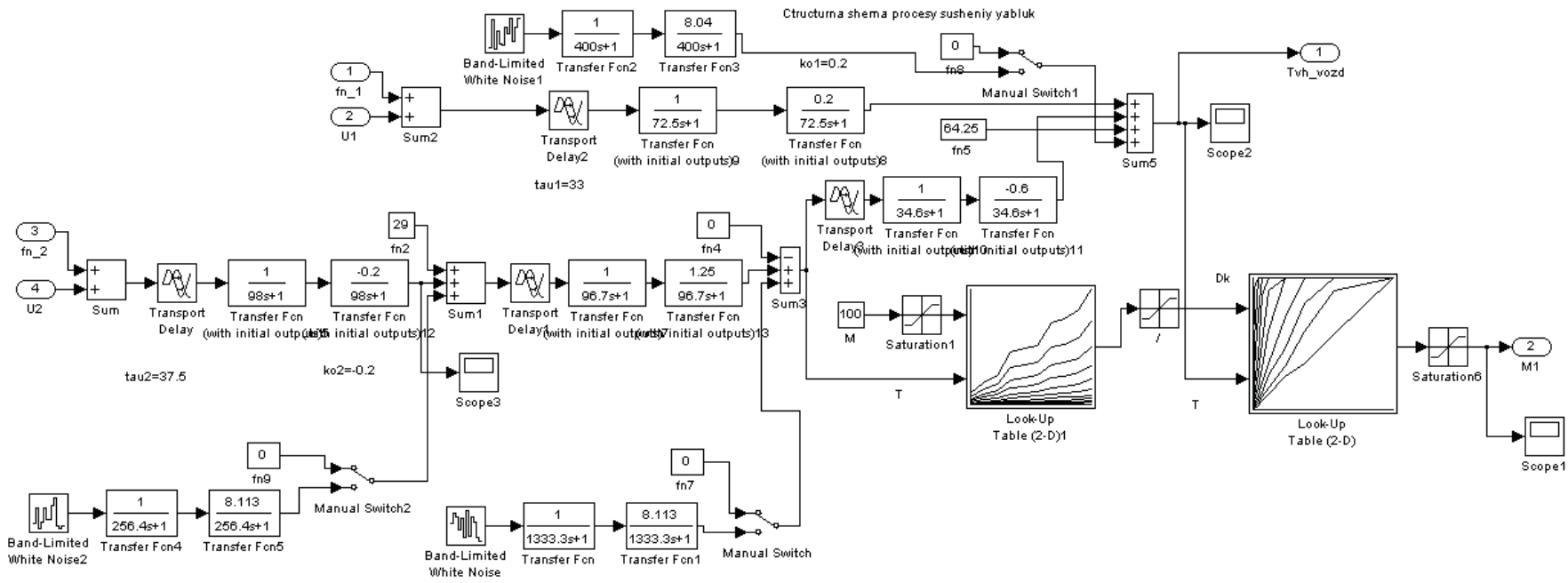

Рис. 6 - Повна модель ОК 
Як результат плідної роботи, було зареєстровано перехідні характеристики (ПХ) повної моделі ОК за всіма трьома виходами (М вх.воз, Т вх.воз) в залежності від значення входів (U1, U2) (дивись рис. 7 і 8 ).

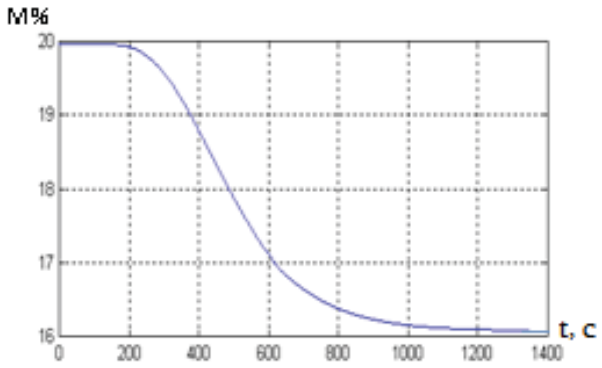

Рис. 7 - ПХ за каналом ( U1-Мвх.воз. )

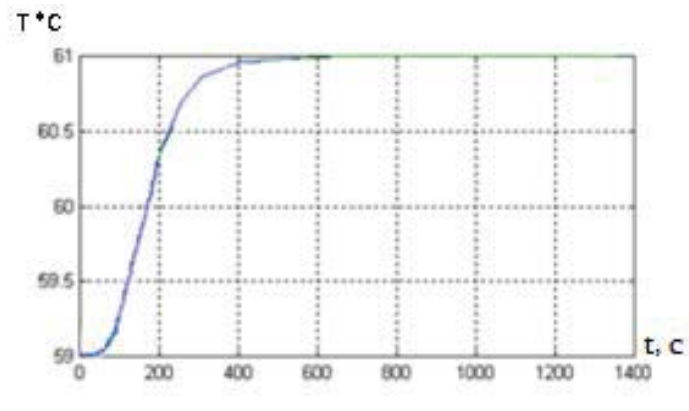

Рис. 8 - ПХ за каналом (U2-Tвх.воз.)

\section{Висновки}

Для ефективного керування процесом сушіння плодоовочевої сировини є необхідним створення адекватної математичної моделі середовища сушарної камери, яка достовірно описуватиме усі фізичні процеси, що протікають у ньому. У ході домлвдження було виявлено мету ТП; проаналізовано та параметризовано його технологічну схему; розроблено структурну схему математичної моделі ОК; зроблено висновок щодо властивостей ОК за його відповідними каналами; проведено серію активних експериментів та параметричну ідентифікацію за ЕПХ, і як результат, отримано математичні моделі ОК за всіма каналами передачі вхідних дій. Було розроблено моделі idдіаграм та підтверджено їх достовірність. Повна модель ОК включає в себе: моделі id-діаграм; моделі об’єкту за всіма каналами передачі вхідних дій; моделі неконтрольованих збурень. Отримана математична модель достовірно описує фізичні процеси, які протікають в середовищі сушарної камери (доведено результатами досліджень) та може використовуватись у подальших дослідженнях.

\section{Список використаних джерел}

[1] Соколов В.А. Автоматизация технологических процессов пищевой промышлености.- М.: ПП, 1991. - 445с.

[2] Благовещенская М.М., Воронина Н.О., Казаков А.В. и др. Автоматика и автоматизация пищевых производств.М.: Агропромиздат, 1991. 239 с.

[3] Королев А. А., Пенто В. Б. Технология производства фруктовых чипсов из слив и абрикосов с помощью комбинированной сушки / Наука и технологии: материалы 12-й науч.-практ. конф., Москва, 2006.- С. 114.

[4] Пенто В. Б. Линия заводской обработки сушеного винограда / Плодоовощные консервы - технология, оборудование, качество, безопасность: сб. материалов междунар. науч.-практ. конф., Москва: ВНИИКОП, 2004. -C. 567-571.

[5] Пенто В. Б., Клюева О. А. Технология производства продукта промежуточной влажности из картофеля / Пищевая промышленность. 2004. № 6 . С . 18-19.

[6] Якубаш I.B. Автоматизація процесу керування конденсаційною сушкою плодо-овочевої сировини 3 використанням термоелектричних теплових насосів (Рукопис). - Одеса: ОНАХТ. - 120с.

\section{References}

[1] V.A. Sokolov, “Automation of technological processes of the food industry,” pp. 130 - 445, $1991 . \quad$ Available: https://www.dissercat.com/content/avtomatizatsiya-tekhnologicheskikh-kompleksov-s-obektami-upravleniyafunktsionalno-svyazanny

[2] M.M. Blagoveshchenskaya, et al., “Automation and automation of food production,“ Agropromizdat, pp. $239,1991$. Available: https://docs.google.com/document/d/1Qiz6tqFOEQvjHtsysv5r8YEBegaIF5uDXD4p1L5mAz0/edit

[3] A.A. Korolev, V.B. Pento, "Technology of production of fruit chips from plums and apricots using combined drying," Science and technology: materials of the 12th scientific-practical conf., Moscow, pp. 114, 2006. Available: http://oj.tsatu.edu.ua/index.php/pratsi/article/view/83

[4] V.B. Pento, "The line of factory processing of dried grapes / Fruit and vegetable canned food - technology, equipment, quality, safety,” collection of articles. materials international. scientific-practical conf., Moscow: VNIIKOP, pp. 567571, 2004.

[5] V.B. Pento, O.A. Klyueva, “Technology of production of intermediate moisture product from potatoes,” Food industry, vol. 6, pp.18-19, 2004. Available: https://findpatent.ru/patent/242/2429704.html

[6] I.V. Yakubash, “Automation of the process of keruvannya by condensation drying of fruit and vegetable syruvin from the vikorystannya of thermoelectric heat pumps (Manuscript). - Odessa: ONAKHT., pp.120, 2019.

Науковий керівник: к.т.н., доцент кафедри АТПіРС Мазур О. В.

Отримана в редакції 12.01.2021. Прийнята до друку 22.02.2021. Received 12 January 2021. Approved 22 February 2021. Available in Internet 31 March 2021. 